\title{
H3C4 wt Allele
}

National Cancer Institute

\section{Source}

National Cancer Institute. H3C4 wt Allele. NCI Thesaurus. Code C154501.

Human H3C4 wild-type allele is located in the vicinity of $6 \mathrm{p} 22.2$ and is approximately $2 \mathrm{~kb}$ in length. This allele, which encodes histone H3.1 protein, is involved in DNA compaction. 